\title{
MANFAAT EDUKASI DENGAN BOOKLET SEBAGAI SARANA PENINGKATAN PENGETAHUAN DAN EFIKASI DIRIORANG TUA PADA ANAK LEUKEMIA LIMFOBLASTIK AKUT YANG MENJALANI KEMOTERAPI
}

\author{
Siti Nur Solikah ${ }^{1}$, Sunaryo Joko Waluyo ${ }^{2}$ \\ ${ }^{1,2}$ Akademi Keperawatan Insan Husada Surakarta \\ sitinurs@akperinsada.ac.id
}

\begin{abstract}
Abstrak
Pendahuluan: Leukemia merupakan kanker pada sumsum tulang dan sel darah. Leukemia Limfositik Akut atau biasa disebut LLA merupakan bentuk umum penyakit kanker pada anak-anak dibawah usia 15 tahun banyak diderita pada anak usia 2-5 tahun. Penyakit kanker ini berasal dari sel darah putih yang tumbuh cepat dan agresif didalam tubuh anak, sehingga anak sangat membutuhkan perawatan dan penanganan dengan kemoterapi. Anak yang telah terdiagnosis penyakit LLA membutuhkan proses pengobatan yang lama (minimal 2 tahun) yang harus dilakukan secara rutin dan teratur pada masa pengobatannya. Orang tua yang memiliki anak dengan LLA mmbutuhkan sumber informasi pengetahuan dan butuh penyesuaian diri dalam merawat anak dngan kondisi LLA.
\end{abstract}

Tujuan: Mendeskripsikan manfaat pemberian edukasi dengan booklet sebagai sarana peningkatan pengetahuan dan efikasi diri orang tua dalam merawat anak dengan penyakit LLA yang menjalani kemoterapi.

Metode: Jenis penelitian Quasi experiment pretest-posttest design without control pada 30 responden. Rancangan penelitian menggunakan one group pretest posttest design. Analisa data menggunakan uji Spearman rank correlation.

Hasil: Hasil penelitian ini menunjukkan (1) Usia responden sebanyak 66,6\% berada pada rentang 26-45 tahun kategori usia dewasa, (2) Pendidikan responden sebagian besar $(66,6 \%)$ adalah pendidikan menengah. (3). Pengalaman orang tua dalam merawat anak LLA sebagian besar $(86,6 \%)$ (4) rata- rata pendapatan responden dibawah Upah Minimum Regional (53,3\%) (5). Hasil uji statistik diperoleh $\rho$-value sebesar 0,003, Ho ditolak.

Kesimpulan: Terdapat manfaat pemberian edukasi dengan booklet terhadap peningkatan pengetahuan dan efikasi diri orang tua pada pasien anak dengan LLA yang menjalani kemoterapi.

Kata kunci: edukasi, pengtahuan, efikasi diri, leukemia limfoblastik akut, kemoterapi

\begin{abstract}
Background: Leukemia is a cancer of the bone marrow and blood cells. Acute lymphocytic leukemia or commonly referred to as LLA is a common form of cancer in children under the age of 15 many suffered in children aged 2-5 years. This cancer comes from white blood cells that grow fast and aggressively in a child's body, so the child is in dire need of care and treatment with chemotherapy. Children who have been diagnosed with LLA require a long treatment process (at least 2 years) that must be done routinely and regularly during the treatment period. Parents who have children with LLA need information sources of knowledge and need adjustment in caring for children with LLA conditions.

Purpose: Describe the benefits of providing education with a booklet as a means of increasing the knowledge and self-efficacy of parents in caring for children with LLA who are undergoing chemotherapy.
\end{abstract}


Methods: Quasi experiment type pretest-posttest design without control for 30 respondents. The research design uses one group pretest posttest design. Data analysis using the Spearman rank correlation test.

Result: The results of this study showed (1) The age of respondents was $66.6 \%$ in the range of 26-45 years in the adult age category, (2) The majority of respondents' education (66.6\%) was secondary education. (3). Parents' experience in caring for LLA children is mostly (86.6\%) (4) the average respondent's income is below the Regional Minimum Wage (53.3\%) (5). Statistical test results obtained $\rho$-value of 0.003, Ho was rejected.

Conclusion: There is a benefit of providing education with booklets on increasing the knowledge and self-efficacy of parents in pediatric patients with LLA who are undergoing chemotherapy.

Keywords: education, knowledge, self-efficacy, acute lymphoblastic leukemia, chemotherapy

\section{Pendahuluan}

Leukemia atau kanker darah adalah penyakit neoplastik yang beragam, ditandai oleh produksi secara tak normal (transformasi maligna) dari sel-sel pembentuk darah di sumsum tulang dan jaringan limfoid. Leukemia merupakan salah satu dari sepuluh kanker pembunuh teratas di Hong Kong, dengan sekitar 500 kasus baru yang didiagnosis setiap tahunnya. Tidak seperti kebanyakan kanker lainnya, leukemia bisa terjadi pada orang dewasa dan anakanak, meskipun lebih sering terjadi pada orang dewasa. Leukemia berpotensi untuk bisa disembuhkan. Leukemia memiliki tingkat kesembuhan tertinggi di antara semua jenis kanker yang ganas.

Leukemia limfositik akut atau biasa disebut LLA merupakan bentuk umum kanker pada anak-anak yang tumbuh cepat dan agresif dibawah usia 15 tahun dengan mayoritas tertinggi pada anak usia 2-5 tahun. Berdasarkan Data dari National Cancer Institute (2013) menyatakan total insiden kejadian kanker per 100.000 penduduk adalah leukemia $(12,8 \%)$, limfoma $(19,7 \%)$, dan myeloma $(5,9 \%)$.

Data tersebut telah mengalami peningkatan dibanding tahun 2012, yaitu leukemia naik 0,3\%; lymphoma dan myeloma naik 0,1\%. Angka kejadian kanker di Amerika Serikat setiap tahun mengalami peningkatan sekitar 35-40 kasus per satu juta penduduk. Kasus LLA di Amerika pada tahun 2015 ditemukan sebanyak 76 kasus (Ward et al, 2016). Angka kejadian leukemia di Indonesia adalah 3/4 kasus dari seluruh kasus keganasan pada anak. Keberhasilan pengobatan leukemia tergantung dari jenis leukemia dan stratifikasi risikonya. 
Kejadian kanker pada anak di Indonesia masih cukup tinggi. Berdasarkan data hasil Riset Kesehatan Dasar (Riskesdas) tahun 2013 menunjukkan bahwa prevalensi kanker pada anak umur 0-14 tahun sekitar 16.291 kasus. Sepertiga dari jumlah kasus kanker anak yang terjadi adalah Leukemia. Penyakit ini paling banyak dijumpai diantara semua penyakit keganasan pada anak lainnya.Yayasan Onkologi Anak Indonesia (2009) menyatakan sebanyak 30\% sampai dengan 40\% dari insiden kanker pada anak merupakan penderita leukemia atau kanker darah yaitu 850 anak. Anak yang telah terdiagnosis penyakit Leukemia Limfoblastik Akut (LLA) membutuhkan proses pengobatan yang lama sekitar minimal 2 tahun, harus rutin, dan teratur berobat.

Kemoterapi adalah salah satu terapi pengobatan kanker yang menjadi pilihan pertama bagi pasien. Menurut Frost (2005) bahwa kemoterapi dapat membunuh sel kanker sebesar 50\%. Terapi pengobatan kemoterapi pada penyakit kanker menggunakan obat-obat kimia disetiap tahapan (induksi, konsolidasi, dan pemeliharaan) (Smeltzer, et al., 2012). Kemoterapi pada pasien kanker terutama pada anak membutuhkan waktu lama, berulang, menimbulkan ketidaknyamanan anak, serta menimbulkan efek samping berupa muntah, kebotakan, stomatitis, konstipasi, diare, neuropati, fatigue dan nyeri (Imbach et al, 2006).

Prinsip kerja kemoterapi adalah membunuh sel-sel kanker yang bekerja dengan cepat, namun kemoterapi juga menimbulkan efek samping yaitu selain membunuh sel-sel kanker juga membunuh sel- sel yang sehat. Seperti pada orang dewasa, penanganan kanker pada anak akan melewati serangkaian proses pengobatan yang utama adalah dengan operasi dan dilanjutkan dengan kemoterapi dengan harapan sel kanker dapat dihancurkan seutuhnya. Sebuah penelitian mengungkapkan bahwa, anak yang menderita kanker akan berpotensi mengalami dampak pengobatan berupa penurunan kualitas hidup. Berbagai dampak tersebut menjadi perlu dilakukan pemantauan respon anak terhadap efek samping kemoterapi perlu diperhatikan dan dipahami oleh orang tua selama merawat anak LLA di rumah maupun saat di RS karena perawatan di rumah merupakan perawatan lanjutan terpenting bagi anak yang menjalani kemoterapi di RS.

Orang tua atau keluarga memiliki peran penting dalam merawat anak yang sakit ketika di rumah. Family Centered Care (FCC) atau perawatan berpusat pada keluarga merupakan prinsip penting dalam asuhan keperawatan khususnya pada 
anak. Perawatan berpusat pada keluarga merupakan perawatan yang melibatkan keluarga dalam melakukan tindakan keperawatan (Wong, 2015). Berdasarkan hasil penelitian Herfiana (2017) menyatakan bahwa dampak fisiologis yang sering terjadi pada anak yang menjalani kemoterapi di RS yaitu alopesia, sariawan, mual dan muntah, serta demam. Salah satu peran perawat adalah sebagai edukator dimana perawat bertugas memberikan edukasi selama memberikan asuhan keperawatan pada anak. Edukasi sebagai intervensi keperawatan mandiri dapat direncanakan untuk meningkatkan kemampuan keluarga dalam perawatan anak karena kebutuhan keluarga yang diperlukan untuk mengoptimalkan perawatan anak sakit adalah edukasi.

\section{Tujuan}

Tujuan dari penelitian yang dilakukan adalah mendeskripsikan manfaat pemberian edukasi dengan booklet sebagai sarana peningkatan pengetahuan dan efikasi diri orang tua dalam merawat anak dengan penyakit Leukemia Limfoblastik Akut (LLA) yang menjalani kemoterapi.

\section{Metode}

Penelitian ini dilakukan di Ruang Rawat Inap Anak Melati 3 Rumah Sakit Umum Daerah (RSUD) DR. Moewardi Surakarta pada tanggal 1 Oktober sampai dengan 31 Desember 2018. Populasi dalam penelitian ini adalah semua orang tua yang mempunyai anak leukemia yang sedang dikemoterapi di rumah sakit DR. Moewardi Surakarta dengan pendekatan consecutive sampling. Besar sampel penelitian dalam penelitian ini 30 sampel. Kriteria inklusi dalam penelitian ini adalah orang tua yang mempunyai anak terdiagnosa leukemia, sedang mendapat kemoterapi minimal selama 2 hari, usia anak maksimal 14 tahun, merawat sendiri anaknya, mampu berbahasa Indonesia, dan bersedia menjadi responden.

Kriteria ekslusi penelitian ini adalah orang tua yang anaknya meninggal saat penelitian dan menghentikan pengobatan dari RSUD DR. Moewardi Surakarta. Sampel dalam penelitian ini sebanyak 30 responden. Variabel bebas dalam penelitian ini adalah edukasi tentang perawatan pasien kanker yang menjalani kemoterapi dengan booklet variabel terikatnya adalah efikasi diri orang tua dalam merawat anak LLA yang menjalani kemoterapi. Rancangan dalam penelitian ini menggunakan one group pretest posttest design, yaitu membandingkan subjek antara satu kelompok sebelum dan setelah diberikan 
edukasi tentang perawatan anak dengan Leukemia Limfoblastik Akut (LLA) yang menjalani kemoterapi di RS. Jenis penelitian Quasi experiment pretest-posttest design without control pada 30 responden. Analisa data menggunakan uji Spearman rank correlation.

\section{Hasil}

Penelitian ini telah diikuti oleh 30 orang responden yang merupakan orang tua dari anak penderita LLA yang menjalani kemoterapi rutin di RS. Berikut hasil penelitian berdasarkan usia, pengalaman merawat dan dukungan serta pendapatan keluarga pasien dengan LLA.

Tabel 1. Distribusi responden berdasarkan usia, pendidikan, pengalaman merawat anak LLA, dukungan, dan pendapatan

\begin{tabular}{|c|c|c|}
\hline Variabel & $\mathbf{N}$ & $\%$ \\
\hline \multicolumn{3}{|l|}{ Usia orang tua (tahun) } \\
\hline $12-25$ & 4 & 13,3 \\
\hline $26-45$ & 20 & 66,6 \\
\hline $46-65$ & 6 & 20 \\
\hline \multicolumn{3}{|l|}{ Pendidikan orang tua } \\
\hline Dasar & 8 & 26,6 \\
\hline Menengah & 20 & 66,6 \\
\hline Tinggi & 2 & 6,6 \\
\hline Pengalaman & Merawat & \\
\hline \multicolumn{3}{|l|}{ Sebelumnya } \\
\hline $\mathrm{Ya}$ & 4 & 13,3 \\
\hline Tidak & 26 & 86,6 \\
\hline \multicolumn{3}{|l|}{ Dukungan keluarga } \\
\hline $\mathrm{Ya}$ & 30 & 100 \\
\hline \multicolumn{3}{|l|}{ Pendapatan (rupiah) } \\
\hline$<812.000$ & 16 & 53,3 \\
\hline$\geq 812.000$ & 14 & 46,6 \\
\hline
\end{tabular}

Berdasarkan tabel 1 diatas diperoleh data hasil penelitian bahwa usia responden sebanyak $66,6 \%$ berada pada rentang 26-45 tahun termasuk kategori usia dewasa. Pendidikan responden sebagian besar $(66,6 \%)$ adalah pendidikan menengah dimana responden telah menyelesaikan pendidikan formal SMP dan SMA dan ada dua responden $(6,6 \%)$ memiliki kategori pendidikan tinggi.

Pengalaman orang tua dalam merawat anak LLA, berdasarian hasil penelitian terdapat 4 responden yang menyatakan bahwa memiliki pengalaman merawat sebelumnya terhadap anak dengan LLA. Pengalaman merawat sebelumnya adalah pernyataan bapak atau ibu dalam pengalamannya merawat anak LLA sebelum merawat yang sekarang. Pengalaman responden dalam merawat anak ditemukan bahwa $86,6 \%$ atau 26 responden belum memiliki 
pengalaman dan $13,3 \%$ (4 responden) telah memiliki pengalaman merawat anak LLA sebelumnya.

Hasil diskusi dengan 4 responden menyatakan bahwa responden mendapatkan informasi merawat anak kanker dari saudara. Hasil penelitian menunjukkan bahwa semua responden (100\%) menyatakan mendapat dukungan penuh dari keluarga dalam merawat anak LLA. Responden yang terlibat dalam penelitian ini menyatakan bahwa selama merawat anaknya yang terdiagnosa LLA mendapatkan dukungan penuh dari keluarga (100\%). Penelitian ini dikuti 30 responden, yang terdiri dari 26 responden adalah ibu dari anak-anak yang terdiagnosa LLA dan 4 bapak yang merawat anak LLA. Responden dalam penelitian ini memiliki fase pengobatan yang berbeda-beda, ada 15 responden pada fase pemeliharaan (maintenance), 6 responden pada fase konsolidasi, dan 9 responden pada fase induksi. Pendapatan responden dalam penelitian ini sebagian besar (53,3\%) dibawah rata-rata MR (Upah Minimum Regional).

\section{Normalitas Data}

Hasil uji normalitas dengan menggunkan uji shaphiro-wilk (X $\leq 50$ responden) terhadap data karakteristik responden dan tingkat efikasi diri orang tua dapat terlihat dalam tabel 2 Normalitas data usia, pendidikan, pengalaman merawat anak LLA, dukungan, dan pendapatan, efikasi diri orang tua.

Tabel 2. Hasil Uji Normalitas data usia, pendidikan, pengalaman merawat anak LLA, dukungan, dan pendapatan, efikasi diri orang tua

\begin{tabular}{llc}
\hline Variabel & p-value & Kesipulan \\
\hline Usia orang tua (tahun) & 0,000 & Tidak Normal \\
Pendidikan orang tua & 0,000 & Tidak Normal \\
Dukungan keluarga & 0,000 & Tidak normal \\
Pengalaman merawat sebelumnya & 0,000 & Tidak Normal \\
Pendapatan (rupiah) & 0,000 & Tidak Normal \\
Efikasi diri orang tua (Pre) & 0,43 & Normal \\
Efikasi diri orang tua (post) & 0,47 & Normal \\
\hline
\end{tabular}

Berdasarkan tabel 2 menunjukkan hasil bahwa data terhadap efikasi diri orang tua pre-post berdistribusi nomal. Data responden terhadap usia, pendidikan, pengalaman merawat sebelumnya, dukunga keluarga, dan pendapatan menunjukkan distribusi data tidak normal. 
Tabel 3. Nilai efikasi diri orang tua pada aspek magnitude, generality, dan strenght

\begin{tabular}{lccc}
\hline Aspek efikasi diri & \multicolumn{2}{c}{ (Mean \pm SD) } & Pre-post \\
\cline { 2 - 3 } & Pre & Post & $3,2 \pm 0,5$ \\
Magnitude & $69,6 \pm 4,5$ & $72,7 \pm 5,1$ & $0,1 \pm 0,7$ \\
Generality & $14,4 \pm 2,2$ & $15,5 \pm 2,9$ & $4,3 \pm 0,03$ \\
Strenght & $38,6 \pm 2,82$ & $44 \pm 2,80$ & \\
\hline
\end{tabular}

Pada tabel 3 dapat ditarik kesimpulan bahwa ada perbedaan nilai efikasi diri orang tua pada aspek magnitude, generality, dan strenght setelah diberikan edukasi. Pada aspek magnitude menunjukkan peningkatan pada saat pre-test dan post-test. Observasi dilakukan peneliti selama 20 hari kepada responden dengan mengamati aktivitas diruang rawat inap khusus anak kanker, hal ini dilakukan peneliti sebagai upaya untuk mengurangi bias terhadap intervensi yang diberikan. Hasil observasi diperoleh bahwa selama jeda waktu tersebut tidak ada mahasiswa atau dokter muda atau tenaga kesehatan lainnya memberikan informasi tentang perawatan anak LLA di rumah maupun saat di RS.

Tabel 4 Gambaran efikasi diri responden

\begin{tabular}{lcccc}
\hline Variabel & Mean & SD & max & $p$-value \\
\hline Efikasi diri orang tua sebelum & 127 & 8,3 & 141 &
\end{tabular}

intervensi (pre-test)

Efikasi diri orang tua setelah 132,2 9,5 148 0,003 intervensi (post-test)

Selisih pretest-posttest $5,2 \quad 8,5$

Hasil uji statistik diperoleh $\rho$-value sebesar 0,003 yang artinya Ho ditolak, sehingga ada pengaruh intervensi pemberian edukasi yang telah diberikan kepada responden terhadap efikasi diri orang tua dari anak dengan LLA di RSUD Dr. Moewardi Surakarta.

\section{Pembahasan}

Studi penelitian Cessna (2014) mengenai efikasi diri dan distress orang tua dengan anak kanker menunjukkan bahwa usia, jenis kelamin, pendidikan, pekerjaan, dan pendapatan memiliki signifikasi yang bermakna terhadap efikasi diri. Studi penelitian Suyami (2012) menyatakan bahwa ibu dalam kategori dewasa muda kemampuan kognitif lebih matang sehingga mampu dalam menerima dan mengolah informasi cepat menyesuaikan diri. 
Menurut Bandura (2005) menyatakan bahwa efikasi diri terbentuk melalui proses belajar yang diterima individu pada tingkat pendidikan formal. Individu yang memiliki jenjang pendidikan yang lebih tinggi akan memiliki efikasi diri lebih tinggi, karena individu lebih banyak belajar dalam mengatasi persoalanpersoalan hidup. Penelitian yang dilakukan oleh Agustini dkk (2016) mengatakan bahwa ada pengaruh edukasi terhadap tingkat kecemasan dan tingkat efikasi diri ibu dalam merawat BBLR.

Menurut Bandura (2005) bahwa efikasi diri terbentuk melalui proses belajar, proses adaptasi, dan pembelajaran yang terjadi dalam siklus hidup. Individu yang memiliki adaptasi yang baik dalam menghadapi keberhasilan dan kegagalan dalam melakukan tindakan akan mempengaruhi tingkat efikasi diri. Apabila individu semakin lama terpapar dengan kesulitan tugas dan pengalaman dalam hidupnya, maka akan semakin tinggi efikasi diri.

Dukungan keluarga adalah pernyataan dari ibu atau bapak bahwa keluarga memberikan dukungan terhadap perawatan di rumah bagi anak LLA. Dukungan terhadap efikasi diri orang tua dalam merawat anak LLA menjadi kunci penting.. Menurut Bloom (dalam Notoatmodjo, 2005), perilaku yang terbentuk di dalam diri seseorang dipengaruhi oleh stimulus luar diri seperti dukungan sosial, keluarga, dan lingkungan maka akan sulit untuk merubah perilaku dan keyakinan diri. Studi (Skarbek, 2006) menyebutkan bahwa dengan adanya dukungan keluarga sangat membantu pasien DM tipe 2 untuk dapat meningkatkan keyakinan akan kemampuannya melakukan tindakan perawatan diri. Penelitian Suyami (2012) menyatakan bahwa pendapatan yang diperoleh keluarga mempengaruhi efikasi diri ibu saat merawat bayi baru lahir.

Pendapatan keluarga merupakan total penghasilan keluarga dalam satu bulan dari berbagai sumber penghasilan. Hasil identifikasi data mentah menunjukkan bahwa pendapatan yang kurang dari UMR tidak mempengaruhi peningkatan efikasi diri seseorang, tetapi sesuai pada keyakinan yang dimiliki seseorang. Berdasarkan hasil Hasil Uji Statistik efikasi diri orang tua dalam merawat anak dengan LLA yang menjalani kemoterapi diperoleh $\rho$-value sebesar 0,003 yang artinya Ho ditolak, sehingga ada manfaat intervensi pemberian edukasi yang telah diberikan kepada responden terhadap pengetahuan dan efikasi diri orang tua dari anak dengan LLA di RSUD Dr. Moewardi Surakarta yang 
menjalani kemoterapi. Hasil tersebut menyimpulkan bahwa dalam penelitian ini terdapat adanya perubahan pengetahuan dan efikasi diri orang tua.

Efikasi diri orang tua dalam hal ini diukur dengan menggunakan kuesioner yang dikembangkan dari aspek-aspek teori efikasi diri. Edukasi yang dimaksud dalam penelitian ini adalah pemberian informasi secara individu tentang perawatan pasien kanker anak yang menjalani kemoterapi dengan media booklet. Hasil tersebut sesuai dengan hasil penelitian yang dilakukan oleh Unsal \& Kasikci (2010) bahwa setelah diberikan pendidikan kesehatan secara signifikan tingkat efikasi diri meningkat. Studi yang telah dilakukan Suyami (2012) juga mendukung hasil penelitian ini, bahwa pemberian edukasi oleh perawat dapat meningkatkan efikasi diri ibu dalam merawat bayinya dan menurunkan kecemasan. Edukasi yang diberikan kepada orang tua dengan anak LLA lebih efektif diberikan dengan menggunakan pendekatan teori pembelajaran. Faktor person merupakan salah satu faktor dalam teori pembelajaran yang dipengaruhi oleh pengalaman penguasaan tindakan, pengalaman permodelan, persuasi verbal, dan kondisi fisik-emosional.

Edukasi yang dilakukan dengan pendekatan terhadap sumber-sumber tersebut diharapakan dapat meningkatkan efikasi diri, khususnya pada orang tua sehingga dapat merawat anak dengan baik. Edukasi atau pemberian pendidikan kesehatan merupakan salah satu aspek penting dari peran perawat sebagai edukator selama memberikan asuhan keperawatan pada anak. Edukasi sebagai intervensi keperawatan mandiri dapat direncanakan untuk meningkatkan kemampuan kkeluarga dalam perawatan anak. Pendidikan kesehatan yang diberikan pada keluarga terhadap risiko infeksi yang timbul selama perawatan diwujudkan sebagai penanggulangan kanker terpadu pada anak dengan LLA (Kemenkes RI, 2014).

Data hasil eksplorasi mengungkapkan bahwa edukasi dengan menggunakan booklet atau buku saku dapat menambah informasi, pengetahuan, dan pemahaman orang tua sehingga dapat meningkatkan kemampuan efikasi diri. Pernyataan informan terkait manfaat dari edukasi adalah: "ya...itu tadi mbak, sekarang saya lebih tahu kesehatan anak, jenis makanan, cara memasak makanan yang benar. Ya itu mbak." manfaatnya pertama yang jelas saya menjadi lebih tenang,dan bersemangatmerawat anak dengan kondisi seperti itu. Yang 
jelas...saya lebih banyak tahu bagaimana merawat anak saya ketika di rumah maupun saat menjalani kemoterapi di RS. Saya bisa memberi semangat pada anak saya lebih...sehingga tadi mbak lihat sendiri, walaupun anak saya panas tinggi tetapi anak saya terlihat kuat. Padahal kalau biasanya, dia manja, nangis...mbak”. Anak saya biasa menangis saat kemoterapi sekarang bisa saya bujuk untuk ikut kemoterapi dengan tenang. Hasil penelitian tersebut diatas didukung dengan teori konsep efikasi diri dari Bandura (2005) yang menyatakan bahwa efikasi diri berpusat pada teori sosial kognitif. Keyakinan yang dimiliki oleh individu merupakan salah satu penentu bagaimana individu berfikir, berperilaku, dan berkeyakinan. Individu yang memiliki efikasi diri tinggi akan memandang permasalahan dan situasi sulit sebagai tugas yang menantang dan harus diselesaikan. Individu dengan efikasi diri tinggi akan mencari upaya untuk memecahkan masalah hingga berhasil dan sukses menyelesaikan tugas. Individu dengan efikasi rendah cenderung berorentasi terhadap dirinya sendiri, berfokus pada kegagalan pribadi, dan hasil yang tidak memuaskan sehingga mudah kehilangan kepercayaan diri serta menghindari tugas yang menantang. Studi penelitian Tahmassian \& Niloufar (2011) menyebutkan bahwa individu yang memiliki efikasi diri yang rendah akan menimbulkan permasalahan emosional dan sosial seperti depresi, kecemasan, dan perubahan perilaku. Penelitian Abedi et al (2013) memperkuat hasil penelitian tersebut bahwa dengan meningkatkan efikasi diri pasien dapat mengendalikan penyakit, pencegahan komplikasi, dan meningkatkan kualitas hidup.

Berdasarkan Penelitian Sarabi et al (2010) yang dilakukan di Marsyhad menyimpulkan bahwa nilai efikasi diri yang dimiliki masing-masing individu dapat dipengaruhi oleh tiga aspek, yaitu tingkat kesulitan, kekuatan keyakinan, dan generalitas. Ketiga aspek tesebut secara langsung akan berpengaruh terhadap individu.

\section{Kesimpulan}

Edukasi menggunakan booklet bermanfaat dalam meningkatkan pengetahuan dan efikasi diri orang tua dalam merawat anak dengan LLA (Leukemia Limfoblastik Akut) yang menjalani kemoterapi. 


\section{Saran}

1. Bagi Pelayanan Kesehatan

Rumah sakit khususnya ruang perawatan anak dapat menggunakan booklet ini untuk usulan dalam salah satu prosedur awal masuk diruangan pasien dengan LLA (Leukemia Limfoblastik Akut) yang sedang menjalani kemoterapi.

2. Bagi Perawat

a. booklet ini dapat digunakan sebagai sarana dalam memberikan informasi kepada orang tua atau keluarga yang memiliki anak dengan LLA (Leukemia Limfoblastik Akut) sehingga dapat meningkatkan pengetahuan dan efikasi diri orang tua merawat anaknya.

b. Perawat dapat melibatkan orang tua dalam proses perawatan khususnya ketika menolong anak saat demam, muntah, dan minum obat saat menjalani kemoterapi.

3. Bagi Orang Tua

a Orang tua dengan anak LLA (Leukemia Limfoblastik Akut) dapat menggunakan booklet sebagai sarana untuk meningkatkan pengetahuan dan efikasi diri dalam merawat anaknya.

b. Orang tua diharapkan dapat mengaplikasikan informasi dalam booklet dikehidupan sehari-hari.

4. Bagi Pendidikan Keperawatan

Booklet yang digunakan dalam penelitian ini dapat digunakan oleh mahasiswa kesehatan dalam memberikan informasi kepada pasien dan sebagai referensi dibidang keperawatan anak

\section{Daftar Pustaka}

Arsyad, A. 2015. Media Pembelajaran. Raja Grafindo: Jakarta

Bandura, A. 2005. Self Efficacy Mechanisms in Human Agency. American Psychologist. 37:122-147

Bandura, A. 2005. Self Efficacy. In V.S Ramachaudran (Ed), Encyclopedia of human behavior. 4:71-81. New York: Academic Press 
Cessna, J. M. 2014. Relationships between Parenting Self-Efficacy and Distress in Parents with and without Cancer. Graduate Theses and Dissertations. http://scholarcommons.usf.edu/etd/4997

Edraki M, et.al. 2012. The Effect of Educational Program on the Quality of Life and Self-Efficacy of Mothers of the Infants with Congenital Heart Disease: A Randomized Control Trial.

Fini, A. I., Adib-Hajbaghery M, Salahshoorian Fard A, Khachian A. The effect of health-promotion strategies education on self-care self-efficacy in patients with bone marrow transplantation. Iranian Journal of Critical Care Nursing. 2011; 4 (3) :109-116

Frost, B.M. 2002. Chemotherapy in Childhood Acute Lymphoblastic Leukemia In Vitro Cellular Drug Resistance and Pharmacokinetics. Comprehensive Summaries of Uppsala Dissertations from the Faculty of Medicine. Uppsala. 85:1189

Hendrix, et al. 2009. A Pilot Study on the Influence of an Individualized and Experimental Training on Cancer Caregiver's Self-Efficacy in Home Care and Symptom Mangement. Home health Nurse. 27(5): 271-278

Iqbal, A., \& Siddiqui Kh S. 2010. Depression Among Parents of Children With Acute Lymphoblastic Leukemia. Shaukat Khanum Memorial Cancer Hospital and Research Centre, Lahore.

Kementrian Kesehatan Republik Indonesia. 2014. Penanggulangan Kanker Terpadu Paripurna. Diakses 9 Maret 2017. Website http://www.depkes.go.id

Lally, P., Jaarsveld, C., Potts, H. W \& Wardle, J. 2009. How Are Habbits Formed: Modelling Habbit Formation In The Real World. Eur J Soc Psych, June 2009, 998-1009

Lemeshow, S., Hosmer, D.W., Klar, J., lwanga, K.S. 1997. Besar sampel dalam penelitian kesehatan. Alih bahasa: Dibyo Pramono. Gadjah Mada University Press: Yogyakarta

Nauli dkk. 2017. Hubungan Dukungan Keluarga dengan Tingkat Kecemasan pada Anak Leukimia Akibat Kemoterapi di RSUD Arifin Achmad Provinsi Riau.Skripsi. Univrsitas Riau.

Notoatmodjo. 2015. Pendidikan Kesehatan dan Ilmu Perilaku. Rineka Cipta: Jakarta.

Potter, P.A \& Perry, A.G. 2015. Buku Ajar Fundamental Keperawatan: Konsep, Proses,dan Praktik. Edisi 4.Volume 1.Alih Bahasa : Yasmin Asih, dkk. EGC: Jakarta

Riskesdas. 2013. Hasil RISKESADAS 2013. Badan Penelitian dan Pengembangan Kesehatan Kementerian Kesehatan Republik Indonesia: Jakarta 
Rahmadina. 2018. Gambaran gejala awal anak dengan leukemia Limfostik akut di RSUD Dr Moewardi Surakarta. Skripsi. UMS

Rustina, Y. 2005. Education program for enhancing parental competency and outcomes of preterm infant. Jakarta

Saeui W, Chintanadilo N, Sriussadaporn P, Sanasuttipun W. 2009. The Effects of an Empowerment Program on the Competence of Caregivers in Caring for Preschool Children with Acute Leukemia Undergoing Chemotherapy . J Nurs Sci. 27(2): 8-17

Salmela, M., Salantera, S., Aronen, E.T. 2010. Coping with hospital related fears: experiences of pre-school-aged children. Journal Of Advanced Nursing 66 (6), 1222- 1231.

Smeltzer, S.C., Bare, B.G., Hinkle, J.L., \& Cheever, K.H. 2008. Brunner \& Suddarth's textbook of medikal surgical nursing. St. Loius: Lippincott Williams \& Wilkins

Suyami. 2012. Pengaruh edukasi dalam perencanaan pulang terhadap tingkat kecemasan dan tingkat efikasi diri ibu dalam merawat bayi baru lahir rendah. Tesis: universitas Indonesia Jakarta

Tehrani, F.J \& Nikpouri, Soghra. 2014. Effect of Health on Knowledge, SelfEfficacy and Health Behaviours of Women with Urinary Tract Infection. International Journal of Urological Nursing Vol. 8 No. 1:3-14

Ünsal, A \& Mağfiret, K.K. 2010. Effect of Education on Perceived Self-Efficacy for Individuals with Arthritis. International Journal of Caring Sciences. January-April Vol 3 Issue 1

Ward, E., DeSantis, Robbins, A. 2014. Childhood and adolescent cancer statistics. CA Cancer J Clin; 64:83

Wong, D.L., Hockenberry, M., Wilson D., Winkelstein, M.L., Schwartz, P. 2013. Buku Ajar Keperawatan Pediatrik ed. 6(2). EGC: Jakarta. 